\title{
Study on the Indication System of Selection and Evaluation for Key Majors in Higher Vocational Colleges
}

\author{
Lu Huang \\ Tourism branch and Dean's Office \\ Chengdu Polytechnic \\ Chengdu, China \\ 66767369@qq.com
}

\begin{abstract}
It is an important indication for the construction and development of majors to build the indication system of selection and evaluation for key majors in higher vocational colleges. This paper analyzes the development course of the evaluation for majors stre tching from undergraduate education to higher vocational education and clarifies the functions and significances of the evaluation for majors. To take the construction of majors in Chengdu Polytechnic as an example, the indication system of selection and evaluation for key majors is built and the applied analysis for evaluation results is conducted in existing majors in the college in order to better optimize the structure of majors and promote the development of key majors and related groups of majors.
\end{abstract}

Keywords - higher vocational education, key major, evaluation, indication

\section{INTRODUCTION}

Higher vocational colleges are the higher educational colleges which undertake the task of vocational-oriented higher education and aim to cultivate technology-based senior special talents. In China, the development course of higher vocational education experienced ups and downs. Higher education gradually transfers from auxiliary and supporting role into an important component for realizing the popularization of Chinese higher education. Meanwhile, it cultivates a large number of high-quality skilled talents for Chinese economic development and industries upgrading and provides strong support for Chinese higher educational development and the economic and social progress.

In recent years, higher vocational education has developed rapidly in China thanks to policies support from state, excellent employment competitiveness and favorable opportunities for further study. However, in the course of development, there also appear some problems such as unbalanced development of majors and educational level. And the construction and efficiency of majors have a direct bearing on the quality of talents training. Therefore, systematic institution for the evaluation of majors and structure of majors in accordance with the needs of industrial and economic development can perfectly facilitate the healthy development of majors and the enhancement of educational quality. ${ }^{[1]}$
II. The Development of the Evaluation for Majors in CHINA

\section{A. The development of the evaluation for majors in} undergraduate colleges

America started its majors' evaluation as early as $1906 .^{[2]}$ While our country began very late. In 1985, Decision of the Central Committee of the Communist Party of China on the Reform of Educational System clearly proposed to carry out the task of higher education evaluation and emphasized that it should attract social forces and institutions to participate in the evaluation. In 1992 and 1993, Ministry of Education evaluated the majors of architecture and chemistry in several key universities. Later, professional assessment on disciplines and evaluation on colleges were widely developed in national undergraduate colleges and universities.

\section{B. The development of the evaluation for majors in higher vocational colleges}

Since 2004, Research Center for China Science Evaluation measures and evaluates Chinese colleges and disciplinary competiveness every year and issues A Report on the Evaluation of Chinese Colleges and Disciplines, including the evaluation on the development of colleges and majors of vocational colleges. In 2008, Ministry of Education began to gradually popularize data acquisition and management system of talents cultivation in higher vocational colleges, which now is available throughout the country. This system has become an important basis for education authorities and vocational colleges to timely grasp and analyze the work of talents cultivation in an all-round manner, issue annual quality report and evaluation and improve the construction of majors in vocational colleges. At present, some standards on the evaluation of vocational colleges have been formulated and certain achievements have been made in our country. However, the system has not yet been formed, much more attention is paid to the evaluation on colleges and the foundation of the evaluation for majors is still weak.

Research project of Chengdu Polytechnic in 2017 (project No.:

17CZYR0330) 


\section{The Significances of The Evaluation on Key Majors}

\section{A. The improvement of the ability on running schools}

Key majors are the long-term priority for higher vocational colleges, the emphasis for the development and plan of majors in colleges and the key to form the competitiveness and characteristics in running schools.[3] In particular, in the process of declaration and construction for national exemplary higher vocational colleges, national key higher vocational colleges and national high-quality vocational colleges, more and more concerns have been put into such achievements as key majors and groups of majors featuring key majors.

\section{B. The development of related majors driven by obvious advantages}

Generally speaking, key majors with advanced educational philosophy, distinctive talents training mode, sound conditions for running schools, high social recognition and good employment can meet the needs of industrial development and local economic construction. As early as 2006, Ministry of Education proposed in Opinions on Comprehensively Improving the Teaching Quality of Higher Vocational Education that higher vocational colleges need to "set up groups of majors led by key majors and supported by related majors in accordance with market requirement and the setup of majors in order to serve communities, industries, enterprises and rural areas and strengthen students' capacity on employment."

\section{The Establishment of Indication System of Selection FOR KEY MAJORS}

\section{A. The principle of the establishment of indication system}

In the first evaluation meeting of higher education in 1985, the principles of the establishment for the indication system of institutions of higher learning in our country was firstly proposed, which are scientific, feasible, comparable and direction-oriented. Over the next three decades, on the basis of such principles, experts derive various evaluation principles. ${ }^{[4]}$ Therefore, based on above-mentioned principles and combining practice survey and analysis, this paper takes Chengdu Polytechnic as an example to build the indication system of selection and evaluation for key majors.

\section{B. The background of the establishment of indication system}

As the object of the establishment of indication system for evaluation, Chengdu Polytechnic is full-time ordinary institution of higher learning supported by People's Government of Chengdu. In addition, it is also an excellent college evaluated by Ministry of Education for the work of talents cultivation in higher vocational colleges, a national (exemplary) key higher vocational college, a national exemplary college to deepen educational reform in innovation and entrepreneurship, an exemplary higher vocational college in Sichuan province and high-quality institution of higher learning in Sichuan province.

Chengdu Polytechnic mainly focuses on the cultivation of high-end technical and skill talents orienting to modern service industry. It has 38 majors under the following 9 categories: finance \& economic, electronic information, civil engineering, tourism and medicine \& health, among which there are 8 national key majors, 3 provincial key majors, 4 municipal key majors, 2 pilot majors of national modern apprenticeships and 4 pilot majors of provincial modern apprenticeships. Such construction is well-developed in the higher vocational colleges of Sichuan province. However, it also encounters the following problems;

- Three years will be offered for the construction after the evaluation and approval of each key major. At present, construction period of most of key majors has been completed by acceptance. But it lacks effective supervision in the later period to ensure the high standard of the construction of majors.

- There are many key majors but limited annual budget. Under such limited resources circumstance, how to allocate reasonably is also a problem. Thus, it requires us to evaluate to ensure that advantageous resources are allocated to those key majors and to find shortcomings in time in the development of majors in order to solve them as quickly as possible.

- It is easy to pay too much attention to rating when some majors are not rated as key majors, which will cause the emphasis on the indications with high scores and neglect of those with low scores. In particular, professional teaching efficiency and the quality of talents cultivation are the foundation of education, which are hard to measure as indications and thus account for lower share in the evaluation.

\section{The main content of indication system}

In the process of the establishment of indication system for evaluation, based on the industrial environment of southwest China, the location of Chengdu Polytechnic--the functional orientation and industrial environment of Chengdu city, the same type higher vocational colleges in Sichuan province and interior environment of Chengdu Polytechnic ${ }^{[5]}$, the main contents of selection and evaluation for key majors are summarized as follows:

a) How well the setup of majors would fit with the regional economic and social development: the orientation of running school and the targets of talents cultivation in the existing 38 majors in Chengdu Polytechnic will be evaluate in accordance with regional development.

b) The achievements of talents cultivation and majors' construction: the closeness of school-enterprise cooperation, establishment of curriculum system, curriculum construction and the quality of talents cultivation will be evaluated in the existing majors.

c) The construction of faculty: the structure of teachers, double- certificated teachers(teachers possess the certifications of both the qualification of teachers and qualification of industry), part-time teachers of each major will be evaluated.

d) The characteristics and functions of majors: the ability of majors to drive the development of related majors, characteristics of majors different from other same-type majors, efficiency of running schools will be evaluated. 


\section{The setup of indication system}

According to the main contents of evaluation, this paper constructs the indication system of selection and evaluation for key majors. Indication system has 7 primary indications, which are majors, talents cultivation mode and the construction of curriculum system, the construction of operation mechanism of school-enterprise cooperation, the construction of faculty, the construction of teaching condition, and the achievements of the construction of majors and exchange and service respectively.
Each primary indication is divided into 2 or 3 secondary indications (see table I). In addition, the concrete content of secondary indication is the combination of quantitative evaluation and qualitative evaluation, which reflects both objective state of current majors and the development prospect of majors.

TABLE I. INDICATION SYSTEM OF EVALUATION FOR KEY MAJORS IN HighER VOCATIONAL COLLEGE

\begin{tabular}{|c|c|c|c|}
\hline $\begin{array}{c}\text { Primary } \\
\text { Indication }\end{array}$ & $\begin{array}{l}\text { Secondary } \\
\text { Indication }\end{array}$ & Standards for Evaluation & Score \\
\hline \multirow[t]{2}{*}{ Majors } & Majors & $\begin{array}{l}\text { Clear philosophy for setting up majors and accurate orientation of majors. Actively } \\
\text { adapt to Chengdu regional economic and social development. Clear plans and } \\
\text { objectives for the development of majors. }\end{array}$ & 5 \\
\hline & $\begin{array}{l}\text { Educational } \\
\text { Objective }\end{array}$ & Clear objectives of talents cultivation with appropriate standards & 5 \\
\hline \multirow{3}{*}{$\begin{array}{l}\text { Talents cultivation } \\
\text { mode and the } \\
\text { construction of } \\
\text { curriculum system }\end{array}$} & $\begin{array}{l}\text { Talents Cultivation } \\
\text { Mode }\end{array}$ & $\begin{array}{l}\text { Close school-enterprise cooperation has formed such mechanism of running schools } \\
\text { as is oriented by the social needs for talents and students' employment and } \\
\text { intensively cooperates with industries and enterprises. Talents cultivation mode } \\
\text { reflects the combination of school-enterprise cooperation, employment positions and } \\
\text { acquisition of knowledge. }\end{array}$ & 10 \\
\hline & Curriculum System & $\begin{array}{l}\text { Scientific and complete curriculum system should accord with the rules of } \\
\text { professional talents cultivation and the characteristics of higher vocational } \\
\text { education. Advanced and applied teaching contents. The method of information } \\
\text { teaching should be fully used. Teaching method should reflect "teaching by doing } \\
\text { and learning by doing". }\end{array}$ & 5 \\
\hline & $\begin{array}{l}\text { Curriculum } \\
\text { Construction }\end{array}$ & $\begin{array}{l}\text { Emphasis on the curriculum reform for majors. Curriculum reform and construction } \\
\text { should be carried out with plans and measures and some achievements should be } \\
\text { made. }\end{array}$ & 5 \\
\hline \multirow{2}{*}{$\begin{array}{l}\text { The construction } \\
\text { of operation } \\
\text { mechanism of } \\
\text { school-enterprise } \\
\text { cooperation }\end{array}$} & $\begin{array}{l}\text { Cooperative } \\
\text { Mechanism }\end{array}$ & $\begin{array}{l}\text { Cooperative enterprises take part in the process of professional talents cultivation } \\
\text { and teaching management. Strong and feasible cooperative system. Standardized } \\
\text { cooperative agreement and management system. }\end{array}$ & 10 \\
\hline & Operative Condition & Sound and well-ordered operating environment for school-enterprise cooperation & 5 \\
\hline \multirow{3}{*}{$\begin{array}{l}\text { The construction } \\
\text { of faculty }\end{array}$} & Team Construction & Rational structure of teachers with low mobility and good team spirit. & 5 \\
\hline & $\begin{array}{l}\text { Double-certificated } \\
\text { Construction }\end{array}$ & $\begin{array}{l}\text { More than } 70 \% \text { teachers with double-certificated qualification and high teaching } \\
\text { level. }\end{array}$ & 5 \\
\hline & Part-time Teachers & $\begin{array}{l}\text { More than } 40 \% \text { part-time teachers undertake the task of teaching professional } \\
\text { courses after the identification of qualifications with standardized management. }\end{array}$ & 5 \\
\hline \multirow{2}{*}{$\begin{array}{l}\text { The construction } \\
\text { of teaching } \\
\text { condition }\end{array}$} & Training Base & $\begin{array}{l}\text { Stable, well-equipped, applied and advanced practice and teaching bases in colleges. } \\
\text { Heavily-used real or emulation career atmosphere. Practical teaching and training } \\
\text { bases outside colleges should match with talents cultivation mode. }\end{array}$ & 5 \\
\hline & Teaching Resources & Resourceful, practical and shared professional teaching resources. & 5 \\
\hline \multirow{2}{*}{$\begin{array}{l}\text { The achievements } \\
\text { of the construction } \\
\text { of majors }\end{array}$} & $\begin{array}{l}\text { The Quality of } \\
\text { Talents Cultivation }\end{array}$ & $\begin{array}{l}\text { More than 95\% of the employment rate of graduates then. More than } 70 \% \text { of job } \\
\text { suited rate with employment positions. Good feedback from employers. }\end{array}$ & 10 \\
\hline & $\begin{array}{l}\text { Characteristics and } \\
\text { Innovation }\end{array}$ & $\begin{array}{l}\text { Distinct school-running characteristics comparing with the same majors of other } \\
\text { colleges. Actively exploration and practice in higher vocational education. }\end{array}$ & 10 \\
\hline \multirow{2}{*}{$\begin{array}{l}\text { Exchange and } \\
\text { service }\end{array}$} & $\begin{array}{l}\text { Cooperation and } \\
\text { Exchange }\end{array}$ & $\begin{array}{l}\text { Domestic and foreign cooperation and exchange should be actively conducted in } \\
\text { industries, teachers and students, which can drive the development of related majors } \\
\text { in colleges. }\end{array}$ & 5 \\
\hline & Social Service & $\begin{array}{l}\text { Achievements of social training and technological service. Being popular in society } \\
\text { and industries. }\end{array}$ & 5 \\
\hline
\end{tabular}

\section{The Application of Evaluation System of Majors}

Based on the indication system of evaluation for key majors, all of majors in colleges will be evaluated and appraised, which can be divided into the following types according to the score. ${ }^{[6]}$ 


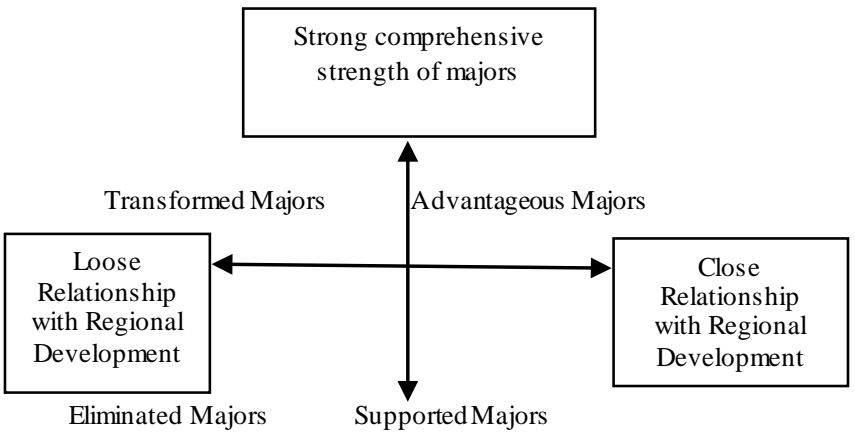

Strong comprehensive

strength of majors

Fig. 1. Classification of Assessment for the Evaluation of Majors

a) Advantageous majors: majors ranking in top 10 in the whole college have very strong comprehensive strength, which can meet the needs of regional economic and social development. In such aspect as development scale of majors, competitiveness of majors, students' employment quality, social evaluation and service, the scores are higher than the average scores of the whole college, such as the majors of hotel management and accounting.

b) Transformed majors: majors ranking in top 15 have strong comprehensive strength. Regional economic and social development are not closely related to corresponding majors, which is required to be transformed appropriately, such as the majors of marketing and applied electronic technology.

c) Supported majors: majors ranking in last 15 have weaker comprehensive strength. Regional economic and social development are closely related to corresponding majors, such as the majors of internet finance and cultural creation and design. d) Eliminated majors: majors ranking in last 10 have weak competitiveness and poor enrollment and employment. Regional economic and social development are not closely related to corresponding majors, which is required to stop the enrollment, such as the majors of tourism English and vehicle testing and maintenance.

\section{CONCLUSION}

The evaluation and selection will be conducted centering on such factors influencing major development as talents cultivation mode, the construction of double-certificated teachers, curriculum and teaching resources, teaching methods, practice and teaching condition and school-enterprise cooperation. The development of general majors will be driven by key majors with profound connotation, strong competitiveness and favorable conditions for running schools. By doing so, the construction of majors and its ability on service in higher vocational colleges will be promoted to enhance on the whole.

\section{REFERENCES}

[1] Rosalina Babo, Higher Education Institutions and Learning Management Systems: Adoption and Standardization[M].Pennsylvania :IGI Global,2011(08)pp.132-156

[2] Colorado Commission on Higher Education, Higher Education Master Plan, 2001-2002[M].Biblio Gov,2013(2),pp.3-20

[3] National Society for Vocational Education. Vocational Education Survey of Minneapolis[M].2010(3),pp.122-130

[4] Yulei, Liao Liping, The Formulation and Implementation Path of "13th Five-Year" Plan in Higher Vocational Colleges[J]. Journal of Vocational Education, 2015(33)pp.5-10

[5] Wu Xue, Chen Xingming, Reshaping the Core: the Fundamental Path of the Establishment of Evaluation System for Majors in China[J]. China Higher Education Evaluation, 2010(4) pp.45-49.

[6] Zhang Guangming, Matrix Technique: the Method of Evaluation and Optimization for Majors in Higher Vocational Colleges[J]. Jiangsu Higher Education, 1995(4) pp.2-64 